\title{
FORMATION OF THE MECHANISMS OF FOOD SECURITY AT THE REGIONAL LEVEL
}

\author{
Alla UZHVA ${ }^{1}$ \\ V.O. Sukhomlynskyi National University of Mykolaiv, Ukraine
}

\begin{abstract}
An important challenge today is to strengthen food security and improve people's lives through increasing competitive products. The crucial vector of forming food security is activities of agricultural business, which are directly responsible to the people for providing sufficient high-quality food. In terms of the desire of Ukraine to integrate as a full partner in the European and world community, the problem of food security is of special significance. The need for food security of Ukraine requires maintaining an appropriate level of food self-sufficiency, which involves the use of state support for domestic agricultural producers and measures of import controls to protect own producers from foreign competition. Subject. The combination of theoretical, methodological approaches and organizational measures to create mechanisms in order to ensure food security at regional level. Methods. Methods of comparison, analysis, theoretical and logical synthesis, graphical method are used. The methodological basis is a comprehensive research method. Purpose. The purpose of the research is to substantiate the need to develop mechanisms to ensure food security of regions in transition to the concept of sustainable development. Results. It is established that the priorities of sustainable development of the agricultural sector in the region are the formation of food security, at the same time, a set of principles is defined that ensure sustainable development of regions; food security indicators are formed for the people of the region. Components of mechanisms are proposed, which regulate food security of regions and contribute to provision of the population with quality products in sufficient quantity. It is found that the basis for monitoring food security in the region and development of mechanisms to ensure it is the reproduction approach that will help to reveal the totality of processes of "production-distributionexchange-consumption" in the defined territory, and to develop a mechanism of management on this basis. Creation of the Complex Regional Program for Food Quality and Security Assurance is proposed, which should include issues of improving mechanisms of protection of the regional food market from low-quality and dangerous products; creation of economic, institutional and social conditions, and mechanisms of wide implementation at the enterprise level of the quality and environment management system as the most effective tool for ensuring quality and security of products meeting the requirements and expectations of consumers.
\end{abstract}

Key words: food security, region, mechanism, agricultural business, food quality.

JEL Classification: Q180, R100, Q130

\section{Introduction}

Sustainable development of any country and the welfare of its population are largely dependent on food security. Food security has a special place in the life support of society as availability of food is a basic condition of human life. At the legislative level, food security is defined as the state of food production in the country that is able to fully meet the needs of every member of the society for food of appropriate quality provided its balance and accessibility to every member of the society (Poltorak, 2015). We fully agree with the statement of P. Sabluk and I. Lukinov that enhancing the level of food security through increasing food production, improving quality and balance for nutrients, and ensuring greater availability of each person for food resources for a healthy diet is a strategic priority of social and economic development of Ukraine (Lukinov, Sabluk, 2000). Thus, food security should be formed in the country as a whole and in each region. This is due to the fact that every region has different climatic conditions, social and economic status of certain territories, demographics and available potential. Thus, food security of the region is understood as an ability of the social and economic system to create and distribute food resources, to provide consistently all categories of the population with food in the defined territory. The crucial vector of forming food security is the activity of agricultural business, which is directly responsible to the people for provision of food of sufficient quality.

The issue of food security is extremely important because it focuses on conceptual directions of the

Corresponding author:

${ }^{1}$ Department of Accounting and Taxation, V.O. Sukhomlynskyi National University of Mykolaiv.

E-mail: kot28125@rambler.ru 
regional agricultural policy in conditions of market economy transformation.

\section{Food Security in Conditions of Sustainable Development of Regions}

Sustainable development, as a world model, integrates ecological, social and ecological measurement of environment in a global perspective. During the research, we consider sustainable development as a permanent growth of potential of the social and economic system that can meet the growing needs of present and future generations for goods and services on the basis of the established optimal territorial and branch structure, which will ensure sustainable use of environmental conditions, drastic reduction in consumption, which do not recover, preserve biological balance and healthy environment.

Transition of agricultural business to sustainable development will mean a qualitative state of the complex actively functioning system, in which the possible negative impact of processes on food security of regions and state of agricultural and ecological systems will be minimized, or eliminated without consequences for them. Thus, in terms of the desire of Ukraine to integrate as a full partner in the European and world community, the problem of food security is of special significance. The world practice shows that only the state, which can guarantee provision of the people with food in conditions, is able to pursue an independent policy.

The need for food security of Ukraine requires maintaining an appropriate level of food selfsufficiency, which involves the use of state support for domestic agricultural producers and measures of import controls to protect own producers from foreign competition. Reliability of food security is both selfsufficiency with food, and availability of funds for their import in required quantities with minimum potential vulnerability of food security of the population in case of difficulties with imports of food (no currency, rising prices, embargoes, etc.).

V. Voloshyn and V. Trehobchuk indicate that in every region of Ukraine, there are specific territorial and production social systems, which are characterized by certain composition and structure, and have significant differences (Voloshyn, Trehobchuk, 2002). So any region is a complex biological and social, and economic system, which includes the following subsystems: nature, society and production. They are interconnected and interdependent, and should be developed, so that they could mutually reinforce and complement each other based on the sustainable use and operation of natural resources potential.

The priority of transition of regions in Ukraine to the model of sustainable development is that interests of social progress, environment and economy are fully balanced, weighted and optimized for the highest possible number of demographic, social, environmental, economic, industrial, technical and technological indicators. Therefore, a complexity is needed, when deciding on the rational use and conservation of environment. Sustainable development of regions defines improvement of quality of life of the people within capabilities of the ecosystem and is the next step after the theory of economic growth. This is a characteristic of sustainability processes or conditions, which can function indefinitely. Regional and local authorities provide economic, social and environmental infrastructure, manage and support it, define policy and standards in the field of implementation of national, regional and local resource and ecological priorities in regions.

Sustainable development of regions should be based on the following principles:

- protection and maintaining a proper state of environment of the region in the process of social and economic development;

- establishing strict liability for the deterioration of environment;

- implementation of organizational and practical measures on greening of economic activity, eliminating sources of negative human impact on environmental quality;

- ensuring public access for the population and organizations to environmental information, including information on hazardous materials and activities;

- carrying out expert assessment of possible environmental impacts of all activities that may negatively affect the environment;

- involving organizations and all categories of the population to achieve objectives of sustainable development.

We believe that these principles should be taken into account in the development and approval of regulations, and social and economic programs of development of the region, ensuring coordinated activities of the state and local authorities to solve practical problems and use of production and resources potential, optimization of territorial organization, providing food and environmental security, productive forces, maintaining social and economic stability of the region.

The development of the agricultural sector of regions is the main basis of food security of the population according to rational nutritional standards. Strategy and tactics of forming food security of Ukraine at the regional level in conditions of high volatility and uncertainty of factors of territorial development is particularly urgent problem for agricultural enterprises of different types of ownership, which produce goods and services of different functions in order to ensure food security of Ukraine at the regional level.

There are the following indicators of food security of the population of the region: the degree of satisfaction of physiological needs of the population for nutrients and energy, diet compliance with the requirements of 
minimization of harmful substances; level of physical and economic availability of different food categories of the population; pricestabilityin thefoodmarket; independence of providing citizens with food and resource support of the agriculture complex on imported supplies; level and pace of development of industries of the domestic agricultural complex, possibility of their expanded reproduction; sizes of strategic food stock in the state reserve and available food reserves (Kapinus, 2002).

The research has found that the main indicators of food security of the region are compliance of the following:

- extent and structure of the final food consumption with rational physiological consumption norms;

- production potential of areas of agricultural business sufficient for production of basic foodstuffs in volume and variety necessary for a safe level of regional exports, food imports;

- volume and structure of exports and imports of food at a safe level for the region defined by capabilities of economically viable production of basic foodstuffs in the region;

- food quality and security with the requirements of sanitary and hygienic, ecological and epidemiological standards of consumption (Iliashenko, 2006).

Thus, maintaining food security requires development of mechanisms of its implementation, taking into account requirements of the population for quality foodstuffs according to rational consumption norms.

\section{Food Quality and Security Assurance}

The main requirement for the quality of foodstuffs is security, which ensures no contaminants, common toxins or any other substance that may make food products harmful to health. Optimal provision with safe, nutritious food is inviolable condition and prerequisite for the protection and promotion of health.

Control over safety and quality of food products is based on checking the final products of companies in Ukraine. However, over the last decade in the world, the tendency has become more significant to realize the importance of an integrated interdisciplinary approach with the consideration of the entire food chain, many of problems related to food safety, arise in the original production. Given that, in recent years, organization of food control in many European countries has undergone reorganization and has become the only institution responsible for the entire food chain - "from farm to consumer." This system has many advantages and deserves so that it is recommended for Ukraine.

The current system in Ukraine for regulation of food security largely comes from the legal definition of what is a dangerous product, programs to enforce the rules in order to remove these foods from the food market and imposing sanctions against those, who violate the relevant regulatory standards. However, it is not very effective because control of the finished product can never be sufficiently complete to ensure that pollution levels are below the established ones, and security, which cannot be controlled in the finished product. Low level of responsibility for violations of standards, rules and regulations and quality of food does not improve the situation in the field of quality and security of food in the country (Mykytiuk, Skydan, 2005). The problem of improving quality and security of food can largely be solved at the regional level through the formation of the regional policy.

A negative factor for improving quality of products is the fact that common interests of new owners of the means of

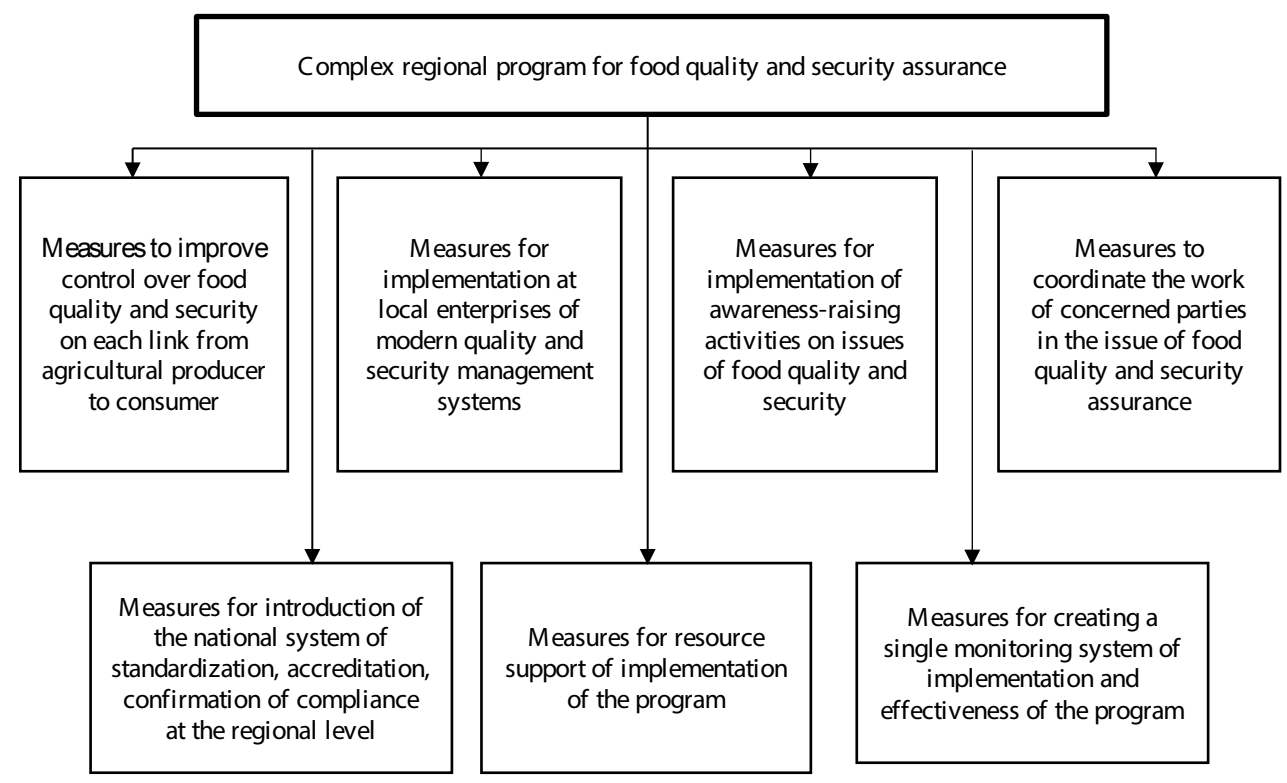

Fig. 1. Integrated approach to food quality and security assurance at the regional level 
production, management and employees of enterprises are to achieve a single temporary benefit, and not to achieve high competitiveness of products and, therefore, survive in the new economy. Consequently, formation of the Complex Regional Program for Food Quality and Security Assurance is proposed, which should include resolution for issues of improving mechanisms to protect regional food market from low-quality and dangerous products; creation of economic, institutional and social conditions, and mechanisms of wide implementation at the enterprise level of the quality and environment management system as the most effective tool for ensuring quality and safety of products meeting the requirements and expectations (Fig. 1).

The issue of improving food quality and safety of domestic food production as one of the main indicators characterizing level of food security of the state lies in the plane of the regional agricultural policy, the priority of which is the improvement of control over quality and safety of food products. Openness should be an important principle of the regional policy in the field of food quality and safety. One of the effective ways for enforcement on compliance with food quality is availability for the society of results of food control.

\section{Mechanisms for Implementation of Regional Food Security}

Today, regions in Ukraine are divided into consuming and producing food due to various factors. Some regions are in need of external food products. Thus, the main conditions of food security in regions are the following:
- economic availability of food;

- rational combination of food of local production and imported as a part of a single economic space of the country;

- lack of interregional trade barriers.

To characterize the state of food consumption in the region, the following systems of indicators are used:

- composition and structure of the population of the region;

- cost of living, cost of the minimum food basket compared to the average monthly wages and welfare payments, average pension;

- number of people with incomes that are below the subsistence level;

- share of spending of the population for purchase of food in the cost structure;

- distribution of income in the society;

- ratio of the monthly food ration with rational norms;

- level and dynamics of food prices;

- development of food trade infrastructure and the retail trade structure.

Development of the food security system in the region provides an integrated approach that includes not only the study of social and economic conditions in the region and elements of the food security system, but also interaction of the state with the system agents including demand and supply management in the food market, facilitating creation of infrastructure of food supply, measures of performance and regulation of the food market in the region. The research has found that the reproduction is the basis for monitoring

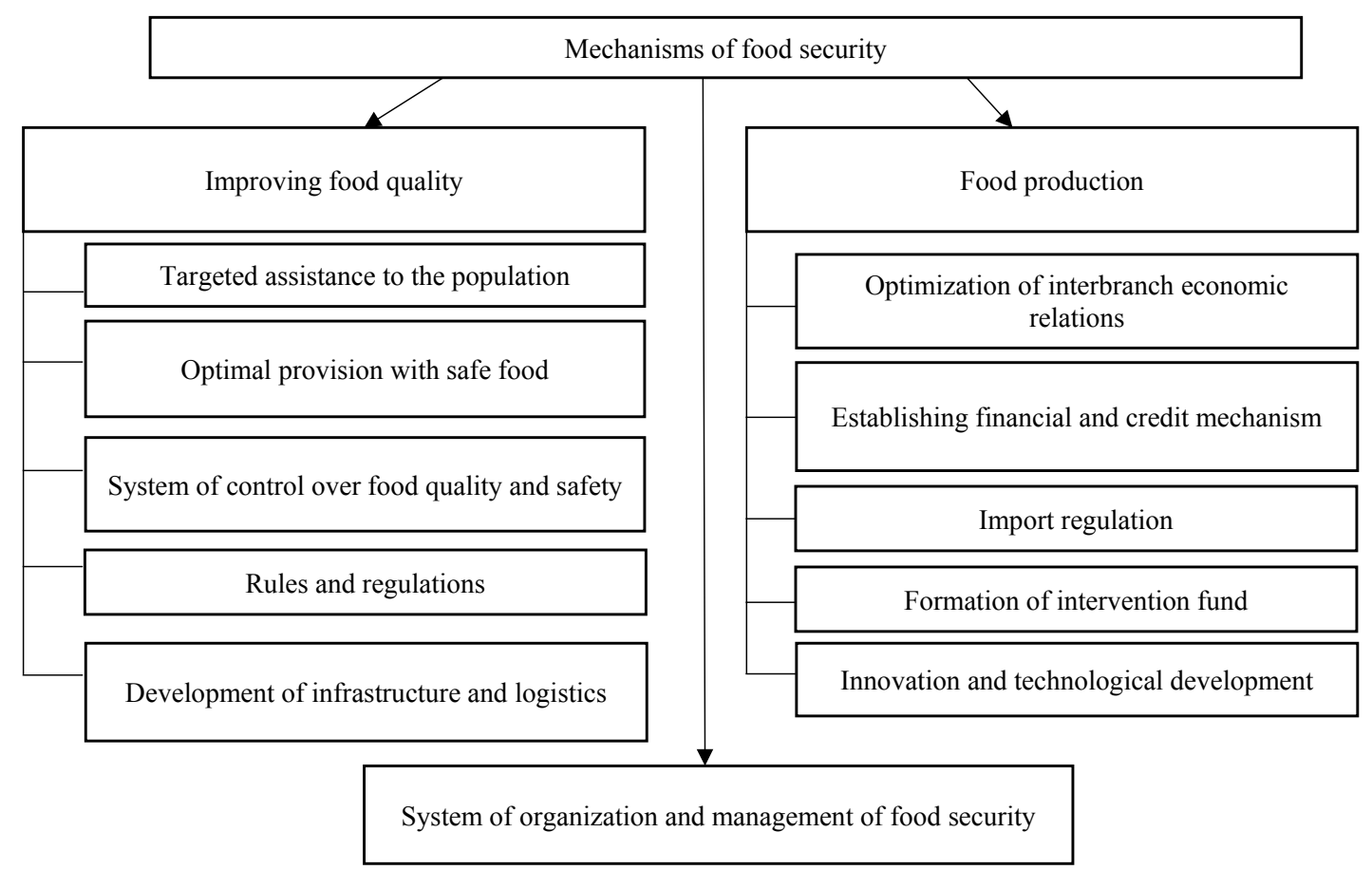

Fig. 2. Mechanisms of food security of regions 
food security in the region and development of mechanisms to ensure it. Thus, reproductive approach allows not only to prove the priority of ensuring formation of food security in individual regions, but also leads to differences of regional strategy from providing the national one. After all, components of the mechanism of food security at the regional level are present in Figure 2.

This approach makes it possible to identify the totality of processes of "production-distribution-exchangeconsumption" in the defined territory, and on this basis to develop a mechanism of control. It is possible to define the regional system, its financial foundation of development, sources of funds and mechanism of their involvement in the territory only if the regional economy is considered as a complete system with its own set of reproductive relations.

The priority at the current stage of development is considered as competitive domestic production of food through development of a large domestic food market, saturation of the domestic consumer market with competitive goods and gradual replacement of imports by domestic products. This is necessary not only to ensure economic and food security of the region and the country as a whole, but also to fight unemployment, provide income growth for both consumers and producers, form the revenue part of budgets of all levels due to tax revenues, develop investment in the economy of the region. Thus, implementation of the reproductive approach to solving the food problem determines the priority of forming the food safety system at the regional level.

\section{Conclusions}

The issue of food security has an important place in concepts of the national security of all developed countries. In terms of the desire of Ukraine to integrate in the European community, the problem of food security is of special significance. The crucial factor of social and economic development of the state is to ensure food security at the regional level. Transformation processes in the agricultural sector should be primarily focused on providing all categories of the population with quality food in the required quantity and assortment. The issue of food quality and security cannot be underestimated as they are important signs of the food chain. Development of the effective national and regional monitoring systems for quality and security of food products, stimulating local enterprises for production of "healthy" food will provide conditions to overcome technical barriers for promotion of products to foreign markets, to increase the credibility of domestic producers in foreign and domestic markets, to contribute to improvement of public health. For regions, production for domestic consumption of basic foodstuffs is an important factor. It is necessary to develop mechanisms for changing types and forms of the state support for agriculture; to improve regulation of food imports, to introduce quotas on imports of competitive products that are produced in abundance in the region; to carry out a single antimonopoly policy in the agricultural sector. We believe that further studies of this problem should pay attention to the assessment of performance of mechanisms of food security at the regional level taking into account characteristics of each region.

\section{References}

Voloshyn, V., \& Trehobchuk, V. (2002). Conceptual Framework for Sustainable Development of Regions of Ukraine. Regional Economics, Vol. 1, p. 7-22.

Iliashenko, V. (2006). Mechanisms of the State Management of Sustainable Development of Food Supply in Ukraine. Collection of Research Papers of NADU, Vol. 1, p. 88-94.

Kapinus, Y. (2002). Food Problem: Ukraine in the International Dimension. State Management in Conditions of Integration of Ukraine in the European Union. Materials of Research and Application Conference, p. 247-248.

Mykytiuk, V., \& Skydan, O. (2005). Formation of Food Security in Ukraine: Regional Aspect - Zhytomyr, Publishing House of State Agricultural and Ecological University, 248 p.

Poltorak, A. (2015). Comprehensive Assessment of Food Security of Ukraine. Economic Journal - XXI, Vol. 7-8 (2), p. 15-18.

Lukinov, I., \& Sabluk, P. (2000). On the Strategy of Transforming Agriculture and Food Security of Ukraine: Scientific Report. Agricultural Economics. Vol. 8, p. 3-36.

\section{Алла УЖВА}

\section{ФОРМИРОВАНИЕ МЕХАНИЗМОВ ПРОДОВОЛЬСТВЕННОЙ БЕЗОПАСНОСТИ РЕГИОНАЛЬНОМ УРОВНЕ}

Аннотация. Важной проблемой настоящего является укрепление продовольственной безопасности и повышение уровня жизни населения на основе увеличения объемов конкурентоспособной продукции. Определяющим вектором формирования продовольственной безопасности является деятельность субъектов аграрного бизнеса, которые несут непосредственную ответственность перед населением за достаточное обеспечение качественным продовольствием. Вусловияхстремления Украины интегрироваться как полноценный партнер в европейское и мировое общество проблема продовольственной безопасности 
приобретала особое значение. Необходимость обеспечения продовольственной безопасности Украины требует поддержание соответствующего уровня продовольственного самообеспечения, которое предусматривает использование государственной поддержки отечественных производителей сельскохозяйственной продукции и употребления мероприятий импортного контроля с целью защиты собственных производителей от иностранной конкуренции. Предмет исследования. Совокупность теоретических, методических подходов и организационных мероприятий по формированию механизмов обеспечения продовольственной безопасности на региональном уровне. Методология. В процессе исследования применены методы сравнения, анализа, теоретического и логического обобщения, графический метод. Методологической основой стал комплексный метод исследования. Цель. Цель исследования заключается в обосновании необходимости формирования механизмов обеспечения продовольственной безопасности регионов в условиях перехода на концепцию устойчивого развития. Результаты. Установлено, что приоритетными направлениями устойчивого развития аграрной сферы региона является формирование продовольственной безопасности, при этом определенно ряд принципов, которые обеспечивают устойчивое развитие регионов; сформированы показатели продовольственного обеспечения населения региона. Предложены составляющие механизмов регуляции продовольственной безопасности регионов, которые будут способствовать обеспечению населения качественной продукцией в достаточном количестве. Выяснено, что в основу мониторинга продовольственной безопасности региона и разработки механизмов ее обеспечения должен быть поставлен воспроизводительный подход, который даст возможность обнаружить всю совокупность процессов «производство-распределениеобмен-потребление» на определенной территории, и на этой основе разработать механизм их управления. Предложено формирование Комплексной региональной программы обеспечения качества и безопасности продовольствия, которая должна предусматривать решение вопросов усовершенствования механизмов защиты регионального продовольственного рынка от некачественной продукции; создание экономических, организационных и социальных предпосылок и механизмов широкого внедрения на уровне предприятий систем управления качеством как наиболее эффективного инструмента обеспечения качества и безопасности продукции, удовлетворения требований и ожиданий потребителей. 